\title{
Downregulation of Cardiac Guanosine 5'-Triphosphate-binding Proteins in Right Atrium and Left Ventricle in Pacing-induced Congestive Heart Failure
}

\author{
David A. Roth, Kazushi Urasawa, Gregory A. Helmer, and H. Kirk Hammond \\ Veterans Affairs Medical Center, San Diego, California 92161; and Departments of Medicine and Pharmacology, \\ University of California, San Diego, La Jolla, California 92161
}

\begin{abstract}
The extent to which congestive heart failure (CHF) is dependent upon increased levels of the cardiac inhibitory GTP-binding protein ( $\mathrm{Gi}$ ), and the impact of $\mathrm{CHF}$ on the cardiac stimulatory GTP-binding protein (Gs) and mechanisms by which Gs may change remain unexplored. We have addressed these unsettled issues using pacing-induced CHF in pigs to examine physiological, biochemical, and molecular features of the right atrium (RA) and left ventricle ( $L V)$. CHF was associated with an $85 \pm 20 \%$ decrease in $L V$ segment shortening $(P<0.001)$ and a 3.5-fold increase $(P=0.006)$ in the $\operatorname{ED}_{50}$ for isoproterenol-stimulated heart rate responsiveness. Myocardial $\beta$-adrenergic receptor number was decreased $54 \%$ in $R A(P=0.004)$ and $57 \%$ in LV $(P<0.001)$, and multiple measures of adenylyl cyclase activity were depressed $49 \pm 8 \%$ in RA $(P<0.005)$, and $44 \pm 9 \%$ in $\mathrm{LV}(P<0.001)$. Quantitative immunoblotting established that $\mathrm{Gi}$ and $\mathrm{Gs}$ were decreased in RA ( $\mathrm{Gi}: 59 \%$ reduction; $P<0.0001$; Gs: $28 \%$ reduction; $P<0.007$ ) and LV (Gi: $35 \%$ reduction; $P<0.008$; Gs: $28 \%$ reduction; $P<0.01$ ) after onset of CHF. Reduced levels of Gi and Gs were confirmed by ADP ribosylation studies, and diminished function of Gs was established in reconstitution studies. Steady state levels for Gs $\alpha$ mRNA were increased in RA and unchanged in $L V$, and significantly more GS $\alpha$ was found in the supernatant (presumably cytosolic) fraction in RA and $\mathrm{LV}$ membrane homogenates after CHF, suggesting that increased Gs degradation, rather than decreased Gs synthesis, is the mechanism by which Gs is downregulated. We conclude that cardiac Gi content poorly predicts adrenergic responsiveness or contractile function, that decreased Gs is caused by increased degradation rather than decreased synthesis, and that alterations in $\beta$-adrenergic receptors, adenylyl cyclase, and GTP-binding proteins are uniform in RA and $\mathrm{LV}$ in this model of congestive heart failure. (J. Clin. Invest. 1993. 91:939-949.) Key words: $\beta$-adrenergic receptors • adenylyl cyclase $\bullet$ GTP-binding proteins $\bullet$ GTP-binding protein transcription • dilated cardiomyopathy
\end{abstract}

\section{Introduction}

In 1962 Whipple et al. ( 1 ), developed an animal model of heart failure analogous to heart failure associated with chronic atrial arrhythmias in humans. They were able to achieve a state of

Address correspondence to Dr. H. Kirk Hammond, Veterans Affairs Medical Center, San Diego (911-A), 3350 La Jolla Village Drive, San Diego, CA 92161.

Received for publication 29 May 1992 and in revised form 13 November 1992

The Journal of Clinical Investigation, Inc.

Volume 91, March 1993, 000-000 venous congestion and cardiac enlargement in dogs after 3-4 wk of continuous rapid atrial pacing. A subsequent paper by Coleman et al. (2), 9 yr later, established that rapid ventricular pacing in dogs was associated with marked abnormalities in left ventricular $(\mathrm{LV})^{1}$ systolic function. After a 15-yr dormancy, this model resurfaced (3-5). This resurrection was due in part to the burgeoning interest in molecular and biochemical alterations associated with heart failure, but also reflected the simplicity and consistency of this model in comparison to others. Pacing-induced cardiac dysfunction is now a much-used animal model for the study of heart failure (6-10).

Despite recent publications regarding various aspects of cardiac function in pacing-induced heart failure, certain important areas remain unexplored. First, the effects of chronic rapid ventricular pacing upon the stimulatory (Gs) and inhibitory (Gi) GTP-binding proteins in the right atrium (RA) are unknown. Our laboratory has an interest in heart rate regulation and chamber-specific changes in signal transduction in the heart (11-14). Since a major means for increasing cardiac output in severe heart failure is by increasing heart rate, factors affecting heart rate regulation are important. Second, what little attention that has been focused upon Gi-mediated events in the setting of pacing-induced heart failure have provided discordant data $(6,7)$. Furthermore, the extent to which heart failure is dependent upon increased levels of cardiac $\mathrm{Gi}$ is unknown. Finally, the impact of heart failure upon cardiac Gs and potential mechanisms by which Gs may change remain almost completely unexplored.

Human congestive heart failure ( $\mathrm{CHF}$ ) has been associated with increased levels of $\mathrm{Gi}$ in the LV (15-17). It has been postulated that increased $\mathrm{Gi}$ may contribute to the inability of the heart to respond to adrenergic stimulation, and therefore may be of pathophysiological importance in CHF. This infers that basal levels of cardiac $\mathrm{Gi}$ can negatively influence $\beta$-adrenergic receptor ( $\beta \mathrm{AR})$-stimulated adenylyl cyclase activity, and suggests that increased cardiac Gi content may contribute to decreased adenylyl cyclase activity. The degree to which cardiac Gi content influences the stimulation of adenylyl cyclase through the $\beta \mathrm{AR}-\mathrm{Gs}-\mathrm{mediated}$ pathway, however, has not been precisely defined. Simply put, is an increase in cardiac $\mathrm{Gi}$ content necessary or sufficient for abnormalities in contractile function?

We have undertaken this study to address these unsettled issues, and to test these hypotheses: ( $a$ ) Pacing-induced CHF will be associated with increased $\mathrm{Gi}$ content and decreased Gs activity in both RA and LV; and $(b)$ decreased Gs activity will

1. Abbreviations used in this paper: $\beta \mathrm{AR}, \beta$-adrenergic receptor; $\mathrm{CHF}$, congestive heart failure; $\mathrm{CON}$, control; $\mathrm{Gi}$, inhibitory GTP-binding protein; Gs, stimulatory GTP-binding protein; GST, glutathion-Stransferase; ICYP, [ ${ }^{125}$ I]iodocyanopindolol; LV, left ventricle; RA, right atrium. 
be associated with decreased steady state levels of Gs $\alpha$ mRNA, suggesting that downregulation of cardiac Gs is caused by decreased synthesis of the protein.

\section{Methods}

Animals, instrumentation, and pacing protocol. Experimental animals included 17 pigs ( sus scrofa), $50 \pm 8 \mathrm{~kg}$ (mean $\pm 1 \mathrm{SD}$ ). 15 control pigs $(51 \pm 16 \mathrm{~kg})$ were examined as well. Seven of these animals underwent thoracotomy and instrumentation but no pacing, and myocardium from these animals underwent biochemical and molecular analyses. The other eight control animals were included in analysis of heart and liver weights (Table I). After acclimatization to human handling, animals received ketamine ( $50 \mathrm{mg} / \mathrm{kg}$, intramuscularly) and atropine sulfate $(0.1 \mathrm{mg} / \mathrm{kg}$, intramuscularly) followed by sodium amytal ( 100 $\mathrm{mg} / \mathrm{kg}$, intravenously). Animals underwent endotracheal intubation and halothane $(0.5-1.5 \%)$ was delivered by a pressure cycled ventilator for the duration of the surgical procedure. Left thoracotomy was performed, and catheters placed in the aorta, pulmonary artery, and left atrium. An ultrasonic crystal micrometer was placed (segment orientation) in the midwall of the anterior free wall of the $L V, 2.0 \mathrm{~cm}$ from the base of the heart, midway between the left anterior descending and its first diagonal branch. An epicardial unipolar lead was placed $1.0 \mathrm{~cm}$ below the atrioventricular groove in the LV. The power generator (Spectrax 5985; Medtronic Inc., Minneapolis, MN) was placed in a subcutaneous pocket in the abdomen. After recovery from thoracotomy, animals underwent initial pharmacological and hemodynamic measurements (see below). Rapid ventricular pacing then was initiated ( $220 \mathrm{bpm}$ for $7 \mathrm{~d} ; 240 \mathrm{bpm}$ subsequently). Hemodynamic tests were obtained every $7 \mathrm{~d}$ thereafter, with pacemakers inactivated for $1 \mathrm{~h}$ before acquisition of data. Pacers were returned to their pretest rates immediately after data collection. After signs of circulatory congestion developed and substantial hemodynamic abnormalities were present, pharmacological tests were repeated and animals were killed $31 \pm 7 \mathrm{~d}$ after initiation of pacing.

Isoproterenol-stimulated chronotropic response. After recovery from thoracotomy ( $14 \mathrm{~d}$ ), animals underwent pharmacological testing using ( - )isoproterenol (11). The animals were placed in a sling, and bolus doses of isoproterenol $(0.05-2.0 \mu \mathrm{g} / \mathrm{kg})$ were given through a venous catheter while heart rate and arterial blood pressure were measured. Since heart failure may affect reflex activation independently of changes in myocardial $\beta$ AR responsiveness, all experiments were conducted in the presence of glycopyrrolate $(0.14 \mathrm{mg} / \mathrm{kg}$, intravenously), a long-acting muscarinic cholinergic antagonist (18), thereby isolating cardiac $\beta A R$ responsiveness to an optimal degree. The dose of glycopyrrolate was selected from pilot studies; the absence of changes in heart rate in response to nitroglycerine-induced hypotension was used as a criterion for successful suppression of vagally mediated reflex modulation. The possibility of acute desensitization induced by isoproterenol during this protocol was a concern. To assess for acute desensitization, protocols began and ended with the administration of a bolus injection of a near maximal dose of isoproterenol $(1.0 \mu \mathrm{g} / \mathrm{kg})$; final heart rate response was not $>5 \%$ less than the initial response, so we assumed that desensitization during isoproterenol testing did not occur. Pharmacological tests were repeated $25 \pm 5 \mathrm{~d}$ after initiation of pacing, when signs of circulatory congestion (tachycardia, tachypnea) and myocardial dysfunction (depressed fractional shortening, increased left atrial pressure) had developed. Data were examined by nonlinear regression analyses of the relationship between logarithm of isoproterenol dose and heart rate change. We have shown previously that thoracotomy alone does not affect the heart rate responsiveness to isoproterenol stimulation (11).

Terminal surgery. After $31 \pm 7 \mathrm{~d}$ of continuous pacing, and $48-72 \mathrm{~h}$ after completion of all pharmacological and physiological tests, animals were anesthetized, intubated, and midline sternotomies made. The heart was removed, rinsed in sterile saline $\left(4^{\circ} \mathrm{C}\right)$, and the coronary arteries rapidly perfused with sterile saline $\left(4^{\circ} \mathrm{C}\right)$. The RA, left atrium, and right ventricular (RV) free wall were removed. The RV, LV, and septum were weighed. RA samples were obtained from identical regions in all animals. Transmural samples of LV free wall were taken midway from base to apex, near the midportion of the left anterior descending coronary artery. Myocardial samples were then frozen $\left(-80^{\circ} \mathrm{C}\right)$. Time from heart removal to placing samples in liquid nitrogen was 5-10 min.

Membrane preparation. Frozen $\left(-80^{\circ} \mathrm{C}\right)$ transmural samples were powdered in a stainless steel mortar and pestle (also $-80^{\circ} \mathrm{C}$ ), placed in Tris buffer, glass-glass homogenized, and contractile proteins extracted $\left(0.5 \mathrm{M} \mathrm{KCl}, 20 \mathrm{~min}, 4^{\circ} \mathrm{C}\right)$. The pellet of a $45,000 \mathrm{~g}$ centrifugation was resuspended in buffer and radioligand binding experiments, adenylyl cyclase studies, and reconstitution studies performed.

$\beta$-adrenergic receptor binding studies. $\beta$-adrenergic receptors were identified using the radioligand [ ${ }^{125} \mathrm{I}$ ] iodocyanopindolol (ICYP; 5-700 pM) in saturation isotherm experiments conducted on crude membrane preparations as previously described $(11,19)$. Protein concentrations were determined by the method of Bradford (20), and assessment of membrane protein yield per mg crude membrane homogenate was performed using the cardiac sarcolemmal membrane marker, $\mathrm{K}^{+}$-stimulated $p$-nitrophenylphosphatase, after the method of Bers (21). Previous experiments have established that $\beta$ receptors are not lost to the supernatant in our membrane preparations and that $\beta \mathrm{AR}$ number is unaffected by thoracotomy alone $(11,19)$.

Adenylyl cyclase assays. Methods were modified from Salomon (22) as previously reported $(13,19)$. The following agents were used to stimulate cAMP production (final concentrations): isoproterenol ( 10 $\mu \mathrm{M}), \mathrm{Gpp}[\mathrm{NH}] \mathrm{p}(100 \mu \mathrm{M}), \mathrm{NaF}(10 \mathrm{mM})$, forskolin $(100 \mu \mathrm{M})$. We found that cAMP production under these conditions was linear with respect to time and protein concentration, and that 3-isobutyl, 2-methylxanthine $(1.0 \mathrm{mM})$, adenosine deaminase $(5 \mathrm{U} / \mathrm{ml})$, or both, had no effect on basal or maximally stimulated cAMP production. Previous experiments established that adenylyl cyclase activity does not distribute to the supernatant of a 45,000 $\mathrm{g}$ centrifugation in our membrane preparation, and that thoracotomy alone does not influence adenylyl cyclase activity (19).

Bacterial toxin-catalyzed ADP-ribosylation. Cholera toxin and pertussis toxin were preactivated in $20 \mathrm{mM}$ Hepes-buffer ( $\mathrm{pH} 8$ ) containing $30 \mathrm{mM}$ DDT and $1 \mathrm{mM} \mathrm{ATP}$ for $10 \mathrm{~min}$ at $30^{\circ} \mathrm{C}$, then set on ice until use. For ADP-ribosylation by cholera toxin, 40-60 $\mu \mathrm{g}$ of membrane protein was incubated (final vol $0.25 \mathrm{ml}$ ) with $50 \mathrm{mM} \mathrm{KH}_{2} \mathrm{PO}_{4}$ (pH 7.6) containing $2.5 \mathrm{mM} \mathrm{MgCl}_{2}, 1 \mathrm{mM}$ EDTA, $1 \mathrm{mM} \mathrm{ATP,} 1 \mathrm{mM}$ DTT, $3 \mathrm{mM} \mathrm{K}$-phosphoenolpyruvate, $10 \mathrm{mM}$ thymidine, $0.004 \mu \mathrm{g} / \mu \mathrm{l}$ pyruvate kinase, $5 \mu \mathrm{M}^{32} \mathrm{P}-\mathrm{NAD}(0.25 \mu \mathrm{Ci})$ and $0.94 \mu \mathrm{g}$ of preactivated cholera toxin for $1 \mathrm{~h}$ at $30^{\circ} \mathrm{C}$. The reaction was terminated by adding an equal volume of Laemmli sample buffer (23). For pertussis toxincatalyzed ADP-ribosylation, $100 \mathrm{mM}$ Tris- $\mathrm{HCl}$ buffer $(\mathrm{pH} 8)$ and 0.25 $\mu \mathrm{g}$ of preactivated pertussis toxin were used instead of $\mathrm{KH}_{2} \mathrm{PO}_{4}$ and cholera toxin, respectively. The resultant radioactive products were separated by $10 \%$ SDS-PAGE as described previously (24). The protein bands specifically radiolabeled by the toxin were excised from gels by using autoradiogram as templates, then counted in a liquid scintillation counter. Assays included NADP ${ }^{+}$to obtain optimal ADP-ribosylation (25).

Quantification of $G s \alpha$ and $G i \alpha_{2}$ by immunoblotting. Assessment of $\alpha \mathrm{s}$ and $\alpha \mathrm{i}$ subunits of $\mathrm{Gs}$ and $\mathrm{Gi}$, respectively, was conducted using standard SDS-PAGE and immunoblotting techniques. Briefly, $100 \mu \mathrm{g}$ of protein from each supernatant and pellet fraction of a 45,000 $\mathrm{g}$ centrifugation of crude myocardial homogenate derived from appropriate transmural samples was electrophoresed on a $10 \%$ denaturing gel for $4 \mathrm{~h}$ at $30 \mathrm{~mA}$. For quantification of cardiac $\alpha$ subunits, GST (glutathion- $S$-transferase, $26.5 \mathrm{kD}$ )-G $\alpha$ subunit fusion protein expression vectors were constructed with pGEX-3X (Pharmacia LKB, Piscataway, $\mathrm{NJ}$ ) and partial cDNA sequences which corresponded to the carboxy terminus of the GTP-binding proteins (fragment 7, F7). These proteins were expressed in Escherichia coli strain NM522 and the resulting fusion proteins (GST-GsF7 and GST-Gi ${ }_{2} \mathrm{~F} 7 ; 31 \mathrm{kD}$ and $30 \mathrm{kD}$, respectively) were purified and quantitated (26), and then used at four different dilutions per gel for standard curve generation. Low molecu- 
lar weight standards were also included on each gel. Proteins were electroblotted onto nitrocellulose membranes (Amersham International, Amersham, UK) for $14 \mathrm{~h}, 70 \mathrm{~V}, 4^{\circ} \mathrm{C}$ (27). Transfer efficiency was recorded by photocopies of membranes dyed with reversible Ponceau staining, and gel retention checked with Coomassie blue staining. Background blocking was accomplished by incubating membranes in Tris-buffered saline ( $\mathrm{pH} \mathrm{7.5)}$ with $2 \%$ nonfat dry milk, $2 \mathrm{~h}, 25^{\circ} \mathrm{C}$. Purified primary polyclonal antibodies (rabbit anti-G proteins: RM/1 Gs $\alpha$; AS/7, transducin, Gi $\alpha_{1}$, Gi $\alpha_{2}$; New England Nuclear, Boston, MA) were diluted 1:600 in $15 \mathrm{ml}$ of TBS with $0.05 \%$ Tween-20 (TTBS, $\mathrm{pH} 7.5$ ) and $1 \%$ nonfat dry milk, and membranes incubated for $14 \mathrm{~h}$, $4^{\circ} \mathrm{C}(28)$. Autoradiographic detection of bands was performed by incubating membranes in $75 \mathrm{ml}$ TTBS with $1 \%$ nonfat dry milk and 15 $\times 10^{6} \mathrm{cpm}{ }^{125}$ I-protein A (New England Nuclear) for $2 \mathrm{~h}, 25^{\circ} \mathrm{C}$ followed by thorough sequential washes in TTBS, and placing against $\mathrm{x}$-ray film (Kodak X-OMAT AR) for $5 \mathrm{~d},-70^{\circ} \mathrm{C}$. The $45-$ and $31-\mathrm{kD}$ bands for Gs $\alpha$ and GST-GsF7, respectively, were removed from the membranes with background controls for gamma counting. Likewise, the 40 - and $30-\mathrm{kD}$ bands for $\mathrm{Gi} \alpha_{1}, \mathrm{Gi} \alpha_{2}$, and GST-Gi ${ }_{2} \mathrm{~F} 7$, respectively, were removed and counted. Using the specific activity of the GST-fusion protein standards and the specific activity of the sample bands of interest, the tissue GTP-binding protein content was calculated. Gs $\alpha$ and Gi $\alpha_{2}$ cDNA were provided by Dr. A. Gilman (Texas Health 'Sciences Center, Dallas, TX) and Dr. Kaziro (Tokyo University, Japan).

Reconstitution assay for $G s$. We modified a reconstitution assay for use with porcine myocardial membranes (29) as previously described $(13,19)$. Reconstitution assays were performed on undiluted $1 \%$ cholate extract, and several serial dilutions, giving a wide range of protein content. We have found that intrinsic adenylyl cyclase activity in extract and cyc- membranes is negligible, and that $\mathrm{NaF}$ stimulation of cyc-membranes yields no cAMP production. In preliminary studies we found CAMP production to be proportional to amount of extract added (from 1 to $120 \mu \mathrm{g}$ ), and the rate of cAMP synthesis is linear with time for $40 \mathrm{~min}$. We performed assays on extracts from experimental animals side-by-side with appropriate control extracts, using the same batch of cyc- membranes, to minimize the potential confounding influence of variation in catalytic subunit concentration in cyc- membranes. Data are expressed as picomoles cAMP produced per 10 minutes as a function of membrane protein used.

Plasma and tissue catecholamine measurements. Blood samples were obtained from animals in the basal state $2 \mathrm{wk}$ after initial thoracotomy, and again just before killing, after CHF was present. Levels of epinephrine and norepinephrine in plasma and myocardium were determined using a sensitive radioenzymatic assay previously described (30), and data are expressed as catecholamine per milligram wet weight of tissue or per milliliter plasma.

Northern blot analysis. Total RNA was extracted from RA and LV using the RNazol method. 20- $\mu \mathrm{g}$ samples, measured spectrophotometrically, were separated by electrophoresis $(14 \mathrm{~h}, 30 \mathrm{~V})$ in a formaldehyde $1.2 \%$ agarose gel. Equal RNA loading was confirmed photographi-

Table I. Sequential Hemodynamics and Fractional Shortening from 15 Pigs

\begin{tabular}{lrrrrr}
\hline & Control & Week 1 & Week 2 & Week 3 & Week 4 \\
\hline LAP $m m H g$ & $13 \pm 1$ & $21 \pm 2^{*}$ & $28 \pm 3^{\ddagger}$ & $30 \pm 4^{\ddagger}$ & $34 \pm 6^{\ddagger}$ \\
PA $m m H g$ & $27 \pm 3$ & $35 \pm 3^{\S}$ & $39 \pm 2^{*}$ & $48 \pm 3^{\ddagger}$ & $43 \pm 4^{*}$ \\
Ao $m m H g$ & $108 \pm 4$ & $90 \pm 4^{*}$ & $90 \pm 2^{\ddagger}$ & $90 \pm 4^{*}$ & $91 \pm 3^{\S}$ \\
\% SEG & $20 \pm 2$ & $13 \pm 2^{*}$ & $9 \pm 1^{*}$ & $3 \pm 1^{\ddagger}$ & $5 \pm 3^{\S}$
\end{tabular}

Data were collected from conscious animals at rest $60 \mathrm{~min}$ after disabling the pacemakers. ${ }^{*} P<0.01 ;{ }^{\ddagger} P<0.001 ;{ }^{\S} P<0.05$ (vs control values).

LAP, mean left atrial pressure, PA, mean pulmonary arterial pressure, Ao, mean aortic pressure, $\%$ SEG $=$ percent segment shortening. cally by ethidium bromide staining and ultraviolet detection. The gel was blotted to nylon membrane and baked for $2 \mathrm{~h}\left(80^{\circ} \mathrm{C}\right)$. The membrane was hybridized overnight at $55^{\circ} \mathrm{C}$ with the ${ }^{32} \mathrm{P}$-labeled riboprobe (antisense mRNA, $5 \times 10^{6} \mathrm{cpm} / \mathrm{ml}$ ) and exposed to $\mathrm{x}$-ray film $\left(-70^{\circ} \mathrm{C}, 4 \mathrm{~h}\right)$. The film was then assessed by densitometry $(390 \mathrm{gel}$ densitometer; Hoefer Scientific Instruments, San Francisco, CA).

Statistics. Data are expressed as mean \pm 1 SD. Specific measurements were compared before and after induction of heart failure in each animal using Student's $t$ test for paired data; data from control vs CHF animals were compared using Student's $t$ test for unpaired data. The null hypothesis was considered unlikely when $P<0.10$, and rejected when $P<0.05$ ( two tailed).

\section{Results}

Characterization of the model. Table I and Fig. 1 show the hemodynamic and LV functional abnormalities associated with chronic rapid ventricular pacing. These data were obtained from conscious, unsedated animals. $1 \mathrm{wk}$ after initiation of pacing, animals had increased basal heart rates, and increased left atrial and pulmonary arterial pressures. Pressures became progressively more abnormal with additional weeks of pacing (Table I). Signs of circulatory congestion (tachypnea, pulmonary rales, ascites) were evident in most experimental animals by the second or third week of pacing. These data establish that severely abnormal cardiac function resulted from 3 to $4 \mathrm{wk}$ of rapid ventricular pacing. Tracking these abnormal hemodynamics and signs of congestion was progressive deterioration of LV systolic function (Fig. 1). Cardiac output decreased from $4.9 \pm 0.5$ to $2.8 \pm 0.5$ liters $/ \mathrm{min}(P<0.001)$. LV segment fractional shortening, an ejection phase index of $\mathrm{LV}$ systolic function, declined progressively during the course of the study. By week 3 , there was an $85 \pm 20 \%$ decrease in segment shortening compared to the prepacing value $(P<0.001)$. The LV end-systolic pressure-dimension ratio, used to assess LV function in a relatively load-independent manner, was reduced at week 3 (control [CON]: $8.9 \pm 1.4$ Torr/mm; CHF: $5.6 \pm 16$

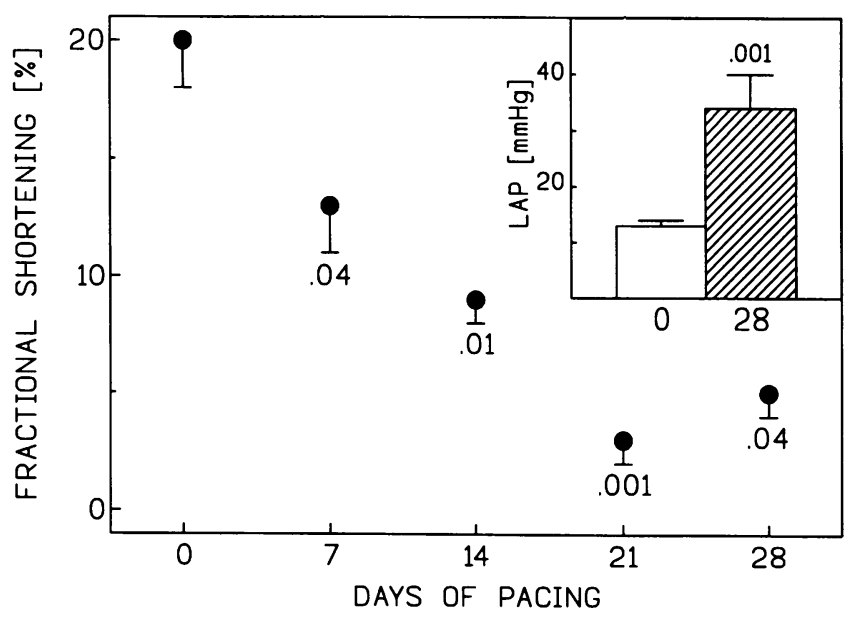

Figure 1. Left ventricular function during chronic rapid ventricular pacing. Fractional shortening (measured by crystal micrometers) progressively decreased during $3 \mathrm{wk}$ of pacing. Points represent mean values; error bars denote $1 \mathrm{SE}(n=15)$. (Inset) Mean left atrial pressure $(L A P)$ was increased in animals after heart failure had occurred. Open bars represent mean values before initiation of pacing; crosshatched bars represent mean values after $28 \mathrm{~d}$ of continuous pacing. Error bars denote $1 \mathrm{SD}(n=15)$. 


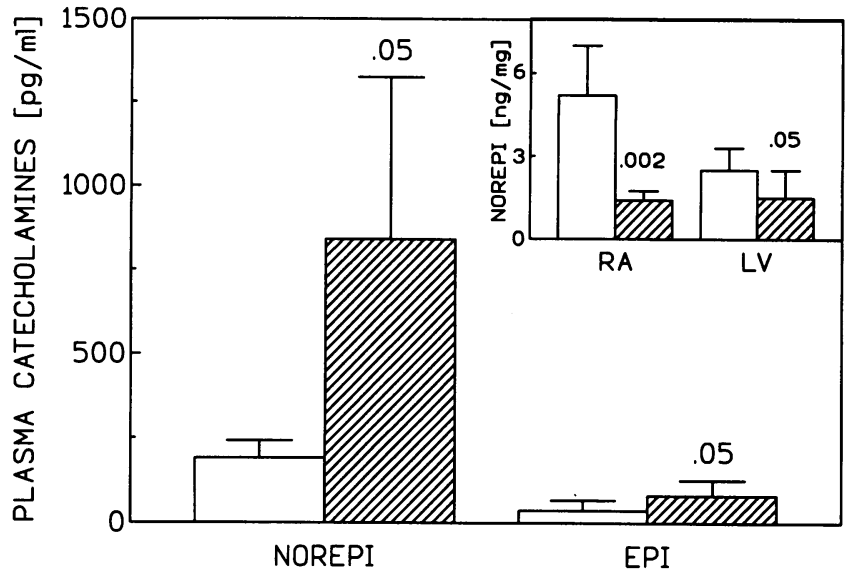

Figure 2. Radioenzymatic measurement of plasma catecholamine levels. After signs of heart failure were evident, animals had elevated levels of plasma epinephrine (EPI) and norepinephrine (NOREPI). Data are expressed as picograms per milliliter plasma. Open bars represent mean values from control animals; cross-hatched bars represent mean values from paced animals; error bars denote 1 SD ( $n$ $=5$, both groups). (Inset) Radioenzymatic measurement of tissue norepinephrine. Compared to control animals, paced animals had decreased norepinephrine in right atrial $(R A)$ and left ventricular $(L V)$ membranes. Data are expressed as nanograms per milligram wet weight. Open bars represent mean values from control animals; cross-hatched bars represent mean values paced animals; error bars denote $1 \mathrm{SD}(n=5$, both groups).

Torr $/ \mathrm{mm} ; P<0.001$ ), establishing that $\mathrm{LV}$ contractility was decreased. Assuming a spherical LV geometry, end-diastolic volume increased $95 \pm 10 \%(P<0.001)$.

At necropsy animals had ascites (mean amount: $2,114 \mathrm{ml}$; range: $300-14,500 \mathrm{ml}$ ), and dilated, thin walled hearts, with all four chambers appearing grossly enlarged. Ventricular to body weight ratios suggested hypertrophy of the RV only (Table II). An additional measure of the congested state was liver weight, which increased nearly twofold (Table II).

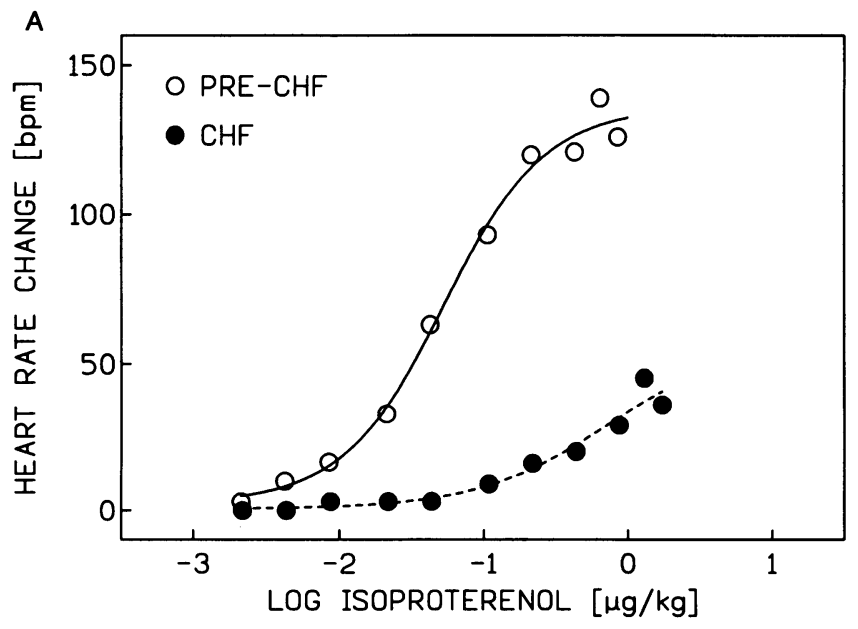

Table II. Left Ventricular and Right Ventricular Weight and Liver Weight

\begin{tabular}{lccc}
\hline & Control & CHF & $P$ \\
\hline Wt $k g$ & $51 \pm 16$ & $50 \pm 8$ & NS \\
LV + IVS $g$ & $134 \pm 22$ & $148 \pm 36$ & 0.20 \\
LV + IVS $\div$ BW $g / k g$ & $2.7 \pm 0.5$ & $2.9 \pm 0.5$ & 0.27 \\
RV $g$ & $43 \pm 8$ & $60 \pm 18$ & 0.03 \\
RV $\div$ BW $g / k g$ & $0.8 \pm 0.1$ & $1.2 \pm 0.2$ & 0.0001 \\
Liver $g$ & $909 \pm 143$ & $1,747 \pm 300$ & 0.0001 \\
Liver $\div$ BW $g / k g$ & $18 \pm 3$ & $36 \pm 7$ & 0.0001 \\
\end{tabular}

Data are from 15 control and 17 paced animals.

LV, left ventricle; RV, right ventricle; IVS, interventricular septum; BW, body weight; $\mathrm{CHF}$, congestive heart failure.

Plasma and myocardial catecholamine content. Fig. 2 shows that 4-5 wk after initiation of pacing, animals had increased levels of plasma norepinephrine (CON: $191 \pm 50 \mathrm{pg}$ / $\mathrm{ml}$; CHF: $840 \pm 483 \mathrm{pg} / \mathrm{ml} ; P=0.05$ ) and epinephrine (CON: $36 \pm 30 \mathrm{pg} / \mathrm{ml}$; CHF: $80 \pm 46 \mathrm{pg} / \mathrm{ml} ; P=0.05$ ). In addition, compared to the control state, myocardial levels of norepinephrine were reduced both in RA (CON: $5.2 \pm 1.8 \mathrm{ng} / \mathrm{mg}$; CHF: $1.4 \pm 0.3 \mathrm{ng} / \mathrm{mg} ; P=0.002$ ) and LV (CON: $2.5 \pm 0.8 \mathrm{ng} / \mathrm{mg}$; CHF: $1.5 \pm 1.0 \mathrm{ng} / \mathrm{mg} ; P=0.05$ ).

Isoproterenol-stimulated chronotropic response. Fig. 3 shows results of studies examining the ability of graded bolus doses of ( - )isoproterenol to increase heart rate. These studies were performed before and after development of CHF in 10 animals. Basal heart rate increased (CON: $109 \pm 16 \mathrm{bpm}$; CHF: $143 \pm 19 \mathrm{bpm} ; P=0.001$ ), maximal isoproterenol-stimulated heart rate decreased (CON: $256 \pm 17$ bpm; CHF: $192 \pm 12$ bpm; $P<0.0001$ ), and maximal isoproterenol-stimulated change in heart rate decreased (CON: $119 \pm 23 \mathrm{bpm}$; CHF: $38 \pm 18 \mathrm{bpm} ; P$ $<0.0001$ ). As shown in Fig. 3, isoproterenol $\mathrm{ED}_{50}$ for heart rate change was increased 3.5-fold after heart failure had developed

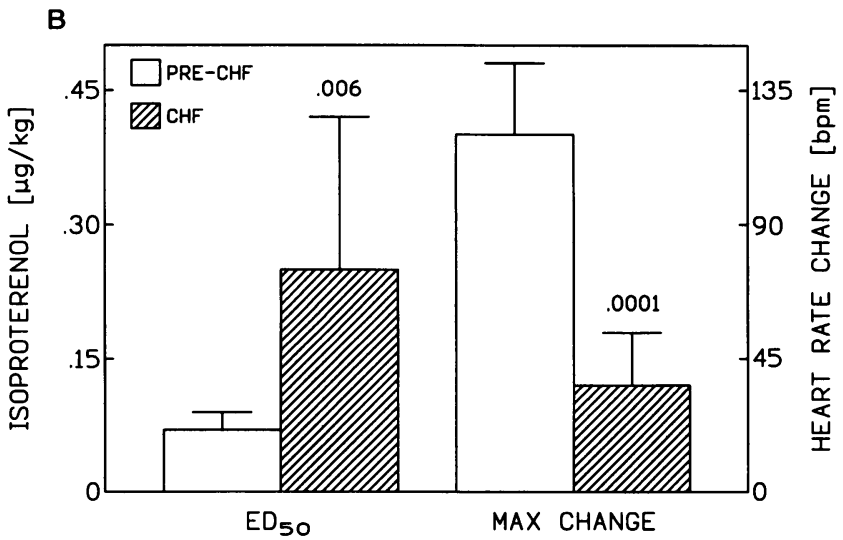

Figure 3. Isoproterenol-stimulated heart rate. $(A)$ Heart rate change as a function of dose. Data from a representative animal, obtained before and after pacing-induced heart failure. The entire curve was rightward and downward shifted after congestive heart failure ( $C H F)$, documenting decreased heart rate responsiveness to isoproterenol stimulation. Open circles represent control values, closed circles represent values after heart failure had supervened. LOG, logarithm (base 10). (B) Data were obtained before and after pacing in each of 10 animals. The dose of isoproterenol required for a $50 \%$ maximal heart rate response $\left(\mathrm{ED}_{50}\right.$; left side of figure) was increased, and the maximal heart rate change was reduced (right side of figure) after signs of heart failure had developed. Open bars represent mean values before pacing (pre-CHF); cross-hatched bars represent mean values after congestive heart failure had developed (CHF); error bars denote $1 \mathrm{SD}(n=10)$. 


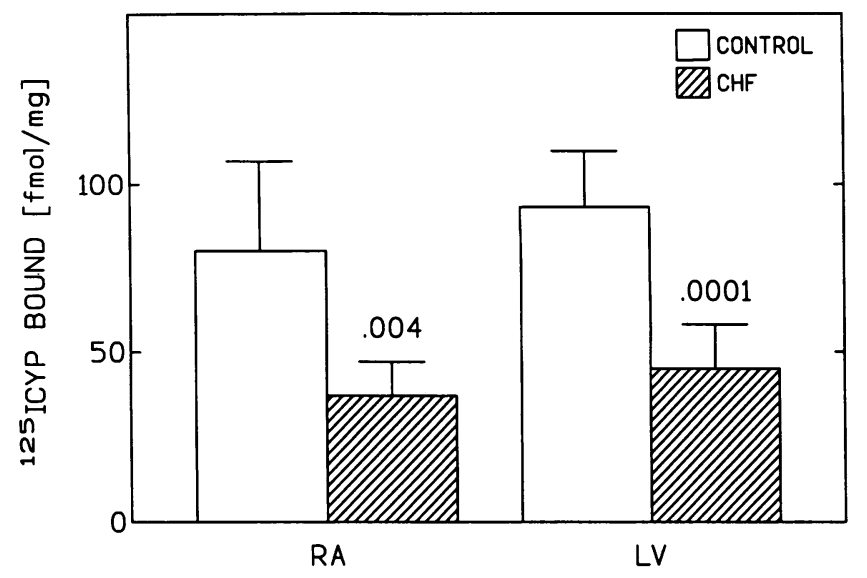

Figure 4. Results of saturation isotherms performed on myocardial homogenates. After heart failure, $\beta$-adrenergic receptor number was reduced in right atrium (RA) and left ventricle (LV). Data are expressed as ICYP bound in femtomoles per milligram. Open bars represent mean values from control animals, cross-hatched bars represent mean values from animals with congestive heart failure (CHF); error bars denote $1 \mathrm{SD}(n=7$, both groups).

(CON: $0.07 \pm 0.02 \mu \mathrm{g} / \mathrm{kg} ;$ CHF: $0.25 \pm 0.17 \mu \mathrm{g} / \mathrm{kg} ; P=0.006$ ). Finally, the slope-relating dose of isoproterenol with heart rate change was decreased after CHF (CON: $69 \pm 16$; CHF: $34 \pm 20$; $P<0.001)$. These data establish that cardiac $\beta$ AR responsiveness to isoproterenol is markedly diminished in animals with pacing-induced CHF.

$\beta$-adrenergic receptor binding studies. Fig. 4 shows the results of saturation isotherm experiments performed in seven control and seven CHF animals. Data shown were obtained from a mean of three saturation isotherms per tissue per animal, performed with triplicate points for each of eight concentrations of ICYP. $\beta$ AR number was decreased after pacing-induced CHF. The extent of $\beta \mathrm{AR}$ downregulation was $54 \%$ in RA (CON: $80 \pm 27 \mathrm{fmol} / \mathrm{mg}$; CHF: $37 \pm 10 \mathrm{fmol} / \mathrm{mg} ; P$ $=0.004)$, and $52 \%$ in LV (CON: $93 \pm 17 \mathrm{fmol} / \mathrm{mg} ; \mathrm{CHF} 45 \pm 13$ $\mathrm{fmol} / \mathrm{mg} ; P<0.001) . K_{\mathrm{d}}$ for ICYP was invariant with pacinginduced CHF in membranes from RA (CON: $68 \pm 17 \mathrm{pM}$; CHF: $80 \pm 27$ pM) and LV (CON: $81 \pm 22$ pM; CHF: $97 \pm 44$ $\mathrm{pM})$. Mean $\mathrm{r}^{2}$ values for the Scatchard analyses were $0.96 \pm 0.04$.

We were concerned that fibrosis or focal hypertrophy might alter sarcolemmal membrane yield after the induction of heart failure, thereby potentially artifactually lowering receptor number. We therefore used the specific activity of $\mathrm{K}^{+}$-pNPPase as a marker for sarcolemmal membrane (21) to confirm that expression of receptor binding per milligram protein was an appropriate means to measure loss of receptors. There was no significant difference in specific activities of this marker between crude membrane homogenates from control and paced animals either in RA (CON: $513 \pm 28 \mathrm{nmol} / \mathrm{mg}$ per $\mathrm{h}$; $\mathrm{CHF}$ : $505 \pm 43 \mathrm{nmol} / \mathrm{mg}$ per $\mathrm{h}$ ) or LV membranes (CON: $461 \pm 37$ $\mathrm{nmol} / \mathrm{mg}$ per h; CHF: $423 \pm 22 \mathrm{nmol} / \mathrm{mg}$ per h).

Adenylyl cyclase activity. $\beta$ AR-dependent and Gs-dependent stimulation of adenylyl cyclase were diminished markedly in RA and LV membranes from pigs after congestive heart failure (Table III). Basal values were lower in RA and LV membranes after CHF. Whether stimulated through the $\beta A R$, through Gs, or more directly through the catalytic subunit of adenylyl cyclase, net cAMP production was diminished. The mean reduction in cAMP production in RA membranes was $49 \pm 8 \%$ (range: $36-58 \%$ ), the mean reduction in LV membranes was $44 \pm 9 \%$ (range: $35-57 \%$ ).

Assessment of $G i$. To determine whether diminution in adenylyl cyclase activity in myocardial membranes from paced animals was associated with increased levels of cardiac $\mathrm{Gi}$, we used two independent measures: pertussis toxin-mediated ADP-ribosylation and quantitative immunoblotting (Fig. 5). We found that pertussis toxin-catalyzed incorporation of ${ }^{32} \mathrm{P}$ was reduced in RA membranes (CON: $18.0 \pm 2.6 \mathrm{pmol} / \mathrm{g}$ wet wt; CHF: $8.6 \pm 1.4 \mathrm{pmol} / \mathrm{g}$ wet wt; $P<0.005$ ) and in LV membranes from animals with heart failure (CON: $13.4 \pm 2.4 \mathrm{pmol} /$ g; CHF: $8.3 \pm 4.2 \mathrm{pmol} / \mathrm{g} ; P=0.03$ ). As an independent, and more specific assay for the assessment of the amount of $\mathrm{Gi} \alpha_{2}$ in cardiac membranes, we used quantitative immunoblotting (Fig. 5) which also showed reduced amounts in RA membranes (CON: $1,949 \pm 220 \mathrm{pmol} / \mathrm{g}$ wet wt; CHF: $797 \pm 231$ $\mathrm{pmol} / \mathrm{g}$ wet wt; $P=0.0001$ ) and in LV membranes from animals with heart failure $(C O N: 1,719 \pm 308 \mathrm{pmol} / \mathrm{g}$ wet wt; CHF: $1,118 \pm 395 \mathrm{pmol} / \mathrm{g}$ wet $\mathrm{wt} ; P=0.008)$. These data support the findings obtained from the pertussis toxin-labeling studies.

Assessment of Gs. To determine whether diminution in adenylyl cyclase activity in myocardial membranes from paced animals was associated with decreased levels of cardiac Gs, we used three independent measures: cholera toxin-mediated ADP-ribosylation (Fig. 6), quantitative immunoblotting (Fig. 6 ), and cyc- reconstitution assays (Fig. 7). We found that chol-

Table III. Stimulation of Adenylyl Cyclase in Right Atrial and Left Ventricular Membranes

\begin{tabular}{lcccccc}
\hline & \multicolumn{3}{c}{ Right atrium } & & \multicolumn{2}{c}{ Left ventricle } \\
\cline { 2 - 4 } \cline { 5 - 7 } & Control & CHF & $P$ & & Control & CHF \\
\hline Basal & $38 \pm 8$ & $22 \pm 2$ & 0.0079 & $83 \pm 18$ & $54 \pm 13$ & 0.019 \\
ISO + Gpp & $100 \pm 13$ & $51 \pm 5$ & 0.0005 & $305 \pm 58$ & $173 \pm 24$ & 0.0015 \\
Gpp & $80 \pm 8$ & $40 \pm 3$ & 0.0001 & $248 \pm 53$ & $123 \pm 19$ & 0.0011 \\
NaF & $140 \pm 23$ & $90 \pm 3$ & 0.0049 & $240 \pm 38$ & 0.0008 \\
Forsk & $219 \pm 24$ & $55 \pm 19$ & 0.0028 & $513 \pm 117$ & $301 \pm 73$ & 0.009 \\
\hline
\end{tabular}

Membranes from control $(n=5)$ and CHF animals $(n=5)$ were studied simultaneously, stimulated with $\beta$-receptor-dependent and $\mathrm{G}_{\mathrm{s}}$-dependent agents, and cAMP production measured. In all cases, myocardium from CHF animals showed marked diminution in cAMP production. Data represent cAMP produced in $\mathrm{pmol} / \mathrm{mg}$ per $\min \pm 1 \mathrm{SD}$, and are net values (basal subtracted). $P=$ control vs CHF, two-tailed $t$ test; ISO, 10 $\mu \mathrm{M}$ isoproterenol; Gpp, $100 \mu \mathrm{M}$ 5'-guanylyimidodiphosphate; NaF, $10 \mathrm{mM}$ sodium fluoride; Forsk, $100 \mu \mathrm{M}$ forskolin. 
A

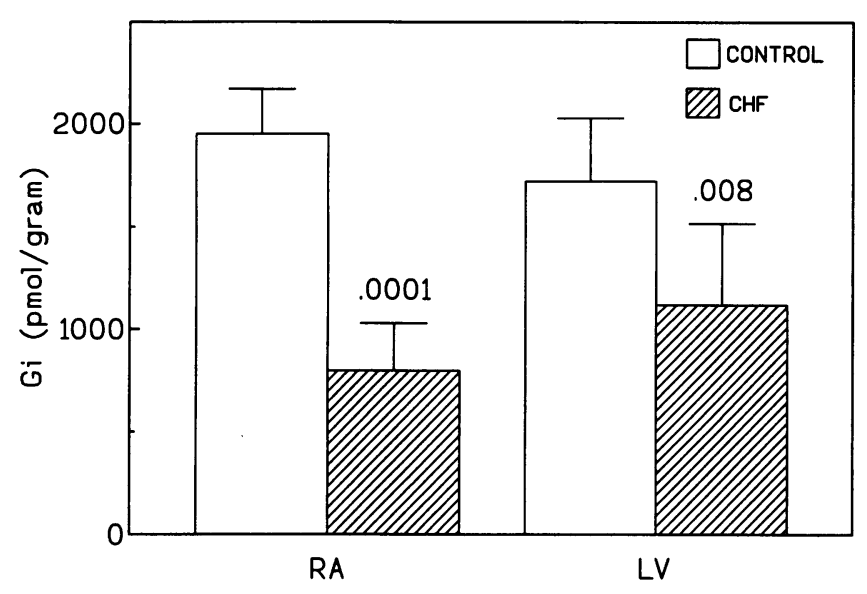

RA
Gi: IMMUNOBLOTTING

LV
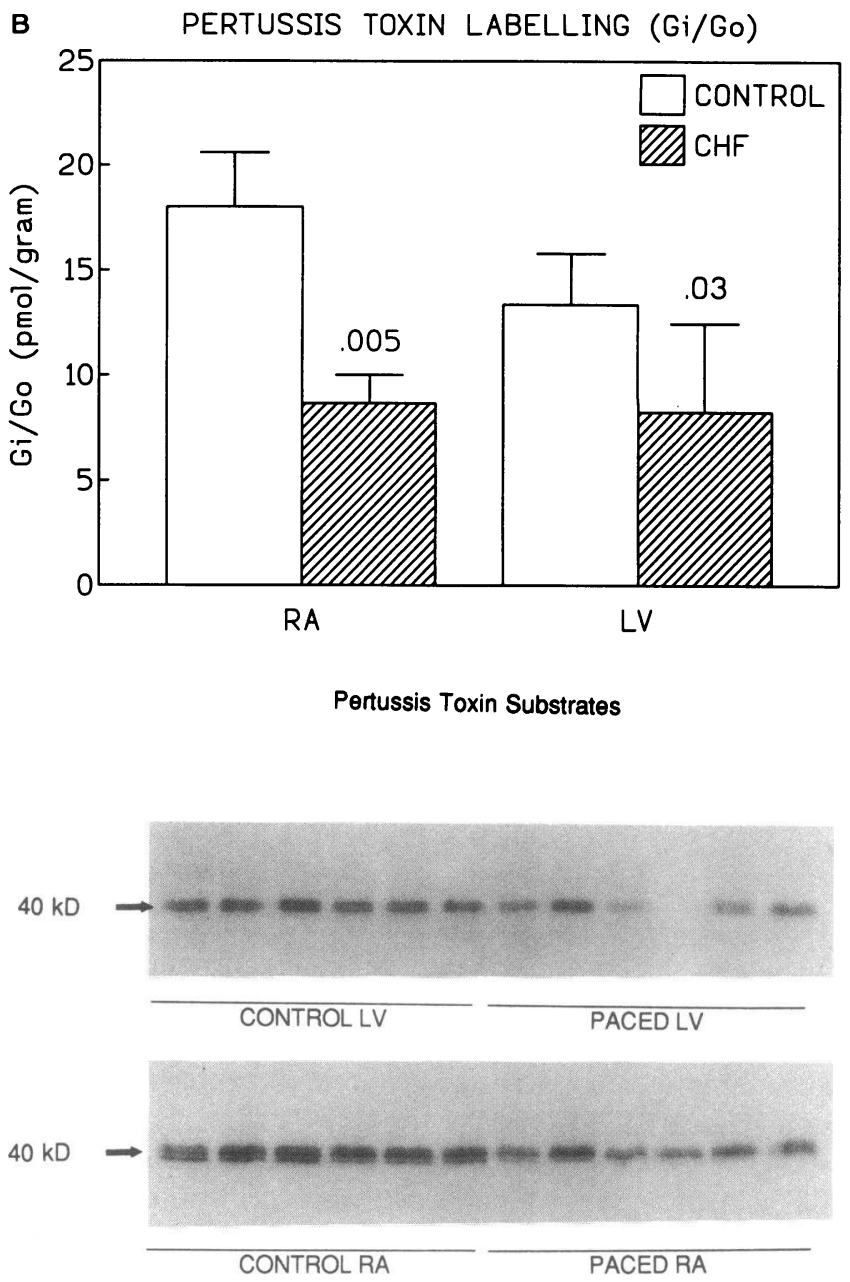

Figure 5. Assessment of cardiac Gi in RA and LV membranes. $(A)$ Quantitative immunoblotting shows decreased Gi in RA and LV from animals with congestive heart failure (CHF). Below the bar graph is a representative autoradiogram of immunoblots from RA and LV from one control (left) and one paced ( right) animal. Both supernatant $(S)$ and pellet $(P)$ fractions of the tissue homogenate were tested, and show insignificant amounts of $\mathrm{Gi} \alpha_{2}$ in the supernatant fraction. Varied amounts of the fusion protein $\mathrm{GST}-\mathrm{Gi}_{2} \mathrm{~F} 7$ were added, then each band was excised and counted. A standard curve was constructed to quantify picomoles of $\mathrm{Gi} \alpha_{2}$ per gram of tissue. $(B)$ Pertussis toxin-mediated ADP-ribosylation shows decreased pertussis toxin substrate in RA and LV from animals with CHF. Below the bar graph is a representative autoradiogram of pertussis toxin-mediated ADP-ribosylation of six control and six paced LV (above), and RA (below) pellet fractions. Each band was excised, counted, corrected for protein distribution, and quantified in picomoles of substrate per gram of tissue. Bars represent mean values, error bars denote $1 \mathrm{SD}(n=6$, all groups).

era toxin-catalyzed incorporation of ${ }^{32} \mathrm{P}$ was lower in RA membranes (CON: $7.3 \pm 2.2 \mathrm{pmol} / \mathrm{g}$ wet wt; CHF: $5.4 \pm 0.6$ $\mathrm{pmol} / \mathrm{g}$ wet wt; $P<0.07$ ) and in LV membranes from paced pigs (CON: $16.2 \pm 2.9 \mathrm{pmol} / \mathrm{g} ; \mathrm{CHF}: 12.3 \pm 1.8 \mathrm{pmol} / \mathrm{g} ; P$ $=0.01$ ).

As an independent, and more quantitative assay for the assessment of the amount of Gs $\alpha$ in cardiac membranes, we used immunoblotting (Fig. 6) which showed that the quantity of Gs was reduced in RA membranes (CON: $447 \pm 64 \mathrm{pmol} / \mathrm{g}$ wet wt; CHF: $320 \pm 64 \mathrm{pmol} / \mathrm{g}$ wet wt; $P=0.007$ ) and in LV membranes from animals with heart failure (CON: $780 \pm 69$ $\mathrm{pmol} / \mathrm{g}$ wet wt; CHF: $625 \pm 121 \mathrm{pmol} / \mathrm{g}$ wet $\mathrm{wt} ; P=0.01)$. These data support the findings obtained from the cholera toxin-labeling studies.

To determine if reduced amounts of Gs, as indicated by the ADP-ribosylation and immunoblotting studies, were associated with reduced function of Gs, thereby contributing to the diminution in adenylyl cyclase activity, we performed reconstitution assays using cholate extracts (Gs-rich) from RA and LV membranes (Fig. 7). Aluminum fluoride stimulation (Gs-dependent) of sarcolemmal membrane extracts from paced animals was decreased both in RA and in LV membranes, suggesting that Gs function was decreased after the development of CHF. For example, the amount of RA sarcolemmal protein required for $10 \mathrm{pmol} / 10 \mathrm{~min}$ cAMP production (Fig. 7) was greater after the development of CHF: (CON: $85 \mu \mathrm{g}$; CHF: 110 $\mu \mathrm{g})$. The amount of LV sarcolemmal protein required for 10 pmol / 10 min cAMP production (Fig. 7) was also greater after the development of CHF: (CON: $58 \mu \mathrm{g}$; CHF: $140 \mu \mathrm{g}$ ). These data support the ADP-ribosylation data and the immunoblots, and extend the paradigm further: not only is the amount of Gs decreased in both chambers, but the function is decreased as well.

Assessment of the distribution of Gs between supernatant (presumably cytosolic) and pellet (presumably membrane-associated) fractions of the myocardial homogenates was performed (Fig. 8). These data show that after CHF, an increased proportion of Gs was found in the supernatant fraction of RA 
A

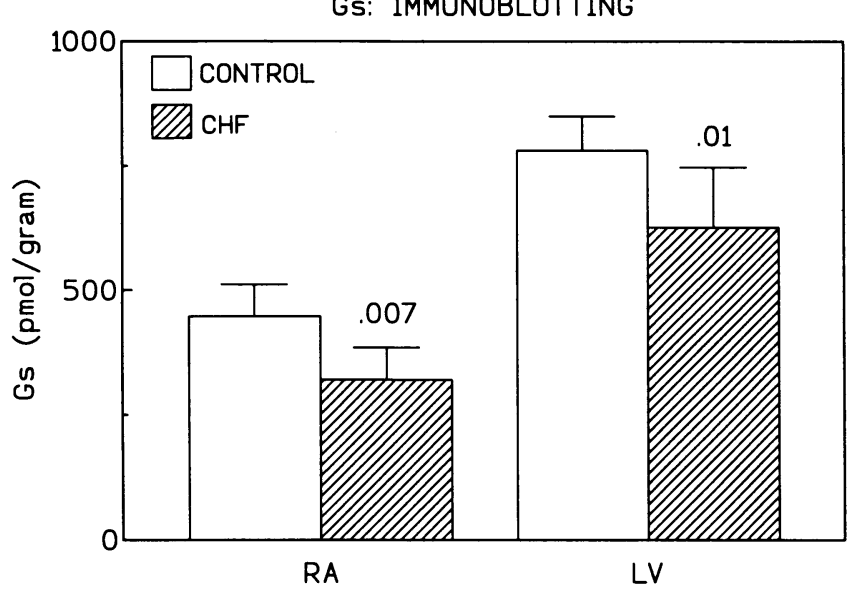

RA

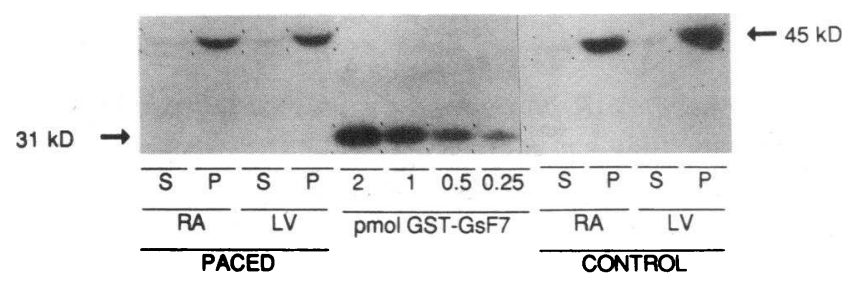

B

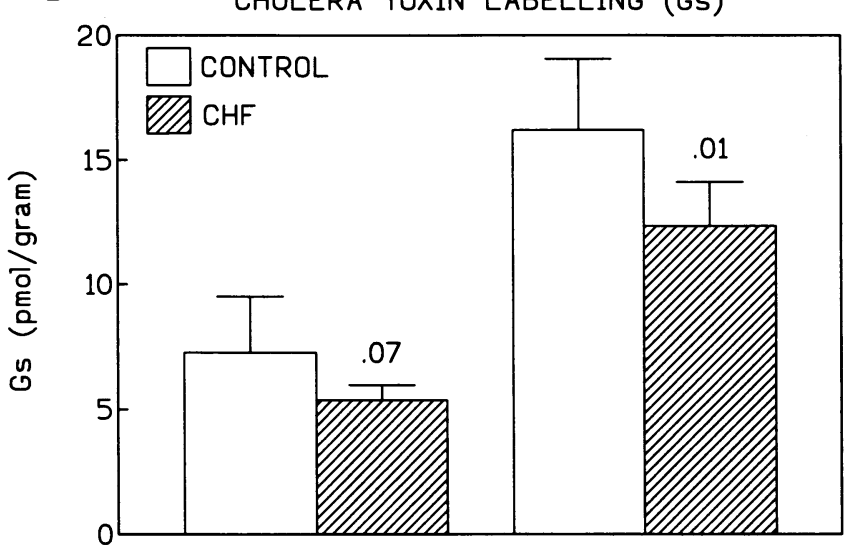

RA

Cholera Toxin Substrates

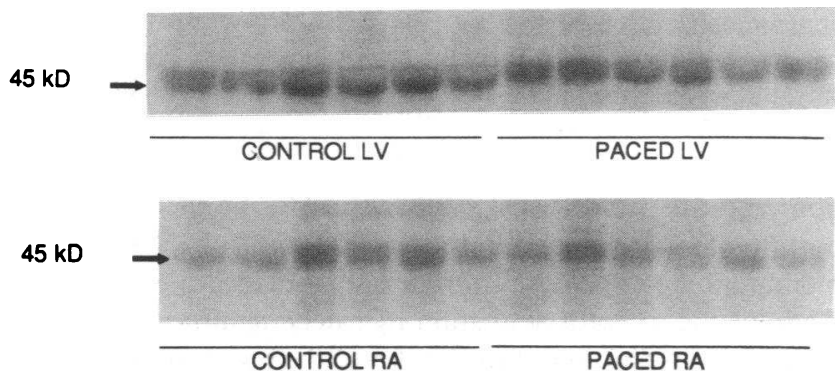

Figure 6. Assessment of cardiac Gs in RA and LV membranes. $(A)$ Quantitative immunoblotting shows decreased Gs in RA and LV from animals with congestive heart failure $(C H F)$. Below the bar graph is a representative autoradiogram of immunoblots from RA and LV from one paced (left) and one control (right) animal. Both supernatant $(S)$ and pellet $(P)$ fractions of the tissue homogenate were tested, and show detectable amounts of Gs $\alpha$ in the supernatant fraction. Varied amounts of the fusion protein GST-GsF7 were added, then each band was excised and counted. A standard curve was constructed to quantify pmols of Gs $\alpha$ per gram of tissue. $(B)$ Cholera toxin-mediated ADP-ribosylation shows decreased cholera toxin substrate in RA and LV from animals with CHF. Below the bar graph is a representative autoradiogram of cholera toxin-catalyzed ADP-ribosylation of six control and six paced LV (above), and RA (below) pellet fractions. Each band was excised, counted, corrected for protein distribution, and quantified in picomoles of substrate per gram of tissue. Bars represent mean values, error bars denote 1 $\mathrm{SD}(n=6$, all groups).

homogenates as assessed by cholera toxin-labeling (CON: 51 $\pm 7 \%$; CHF: $63 \pm 6 \% ; P=0.0097)$. After heart failure, an increased proportion ( $35 \pm 5 \%$ increase; $P=0.005$ ) of Gs was found in the supernatant fraction of LV homogenates as assessed by immunoblotting (data not shown). These data suggest a redistribution of $\mathrm{Gs}$ from the membrane fraction to the cell cytosol during the development of CHF.

Northern blotting. Fig. 9 shows Northern blots performed to assess steady state levels of Gs $\alpha$ mRNA from RA and LV membranes from control and CHF animals. Densitometry was used to assess the autoradiographs, and data are reported in arbitrary units which reflect blot density. LV levels of Gs $\alpha$ mRNA were unchanged by heart failure (CON: 6,306 \pm 337 ; CHF: $6,121 \pm 1,888$ ). In contrast, RA levels of Gs $\alpha$ mRNA were increased in animals with heart failure (CON: 6,802 $\pm 1,355$; CHF: $9,127 \pm 46 ; P<0.04)$.

\section{Discussion}

This study provides three new findings regarding CHF. First, pacing-induced $\mathrm{CHF}$ is associated with striking alterations in multiple elements of the $\beta \mathrm{AR}-\mathrm{G}$-protein-adenylyl cyclase pathway in both RA and LV membranes. Myocardial $\beta$ AR downregulation is found, which is similar in magnitude in both chambers. In addition, multiple measures of adenylyl cyclase activity, whether stimulated through the $\beta \mathrm{AR}$, Gs, or directly through the catalytic subunit, are depressed. Both heart rate responsiveness and LV systolic function, measured in nonsedated conscious animals for the first time, were depressed, providing physiological correlates for biochemical evidence of depressed signal transduction through the $\beta \mathrm{AR}-\mathrm{G}$-protein-adenylyl cyclase pathway. Second, two independent measures of $\mathrm{Gi}$ showed this signal transducing protein is decreased in this model of heart failure in both RA and LV. The precise mechanism for downregulation of cardiac Gi was not established. However, downregulation of cardiac $\mathrm{Gi}$ in conjunction with marked depression of $\beta A R$-mediated signal transduction suggests that increased $\mathrm{Gi}$ is not a necessary component for heart failure. Third, cardiac Gs, measured by three independent methods, was decreased in both RA and LV in animals with CHF. Since steady state levels of Gs $\alpha$ mRNA were not decreased, it is likely that reduced Gs reflects increased degrada- 
A

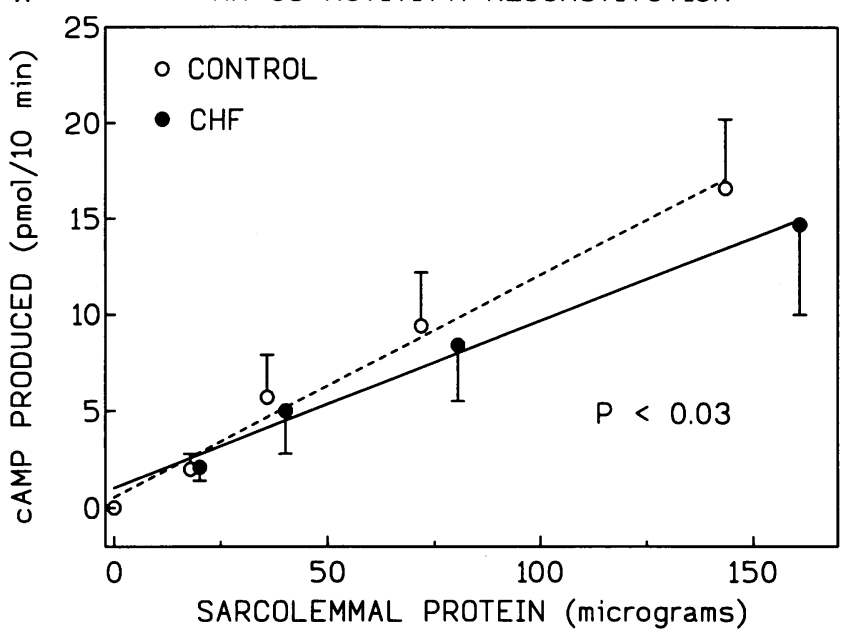

B

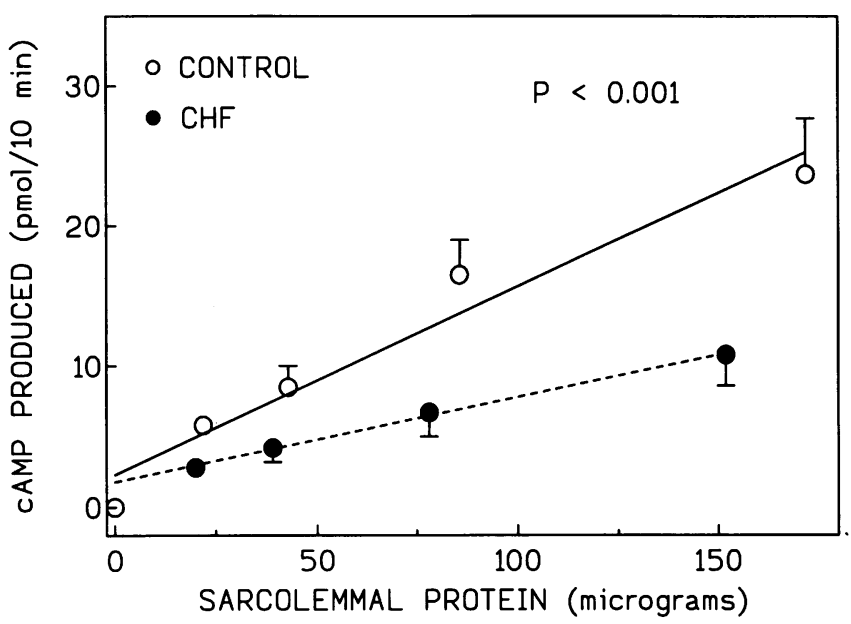

Figure 7. Reconstitution of Gs into cyc- lymphoma cell membranes. $(A)$ Cholate extracts (Gs rich) of right atrial membrane homogenates were stimulated (aluminum fluoride, $10 \mathrm{mM}$ ) and cAMP production was measured. Reconstituted Gs activity was decreased in right atrial membranes from animals with congestive heart failure (CHF). (B) Cholate extracts (Gs rich) of left ventricular membrane homogenates were stimulated (aluminum fluoride, $10 \mathrm{mM}$ ) and cAMP production was measured. Reconstituted Gs activity was decreased in left ventricular membranes from animals with congestive heart failure. Points represent mean \pm 1 SD from each group ( $n=6$, both groups). In all assays, no cAMP activity was detected when extract was not added (corresponding to 0,0 coordinates on the graphs). For simplicity, this point is shown as a clear circle only, but was included in the linear regression analyses for all assays.

tion rather than decreased synthesis of Gs. An increased proportion of Gs was found in the supernatant from RA and LV membrane homogenates from paced animals, suggesting that $\beta$-adrenergic receptor activation by catecholamines, with subsequent redistribution of cardiac Gs to the cell cytosol, may be a mechanism by which Gs is downregulated in this model. This is the first study to provide data suggesting a possible mechanism for cardiac Gs downregulation in vivo.

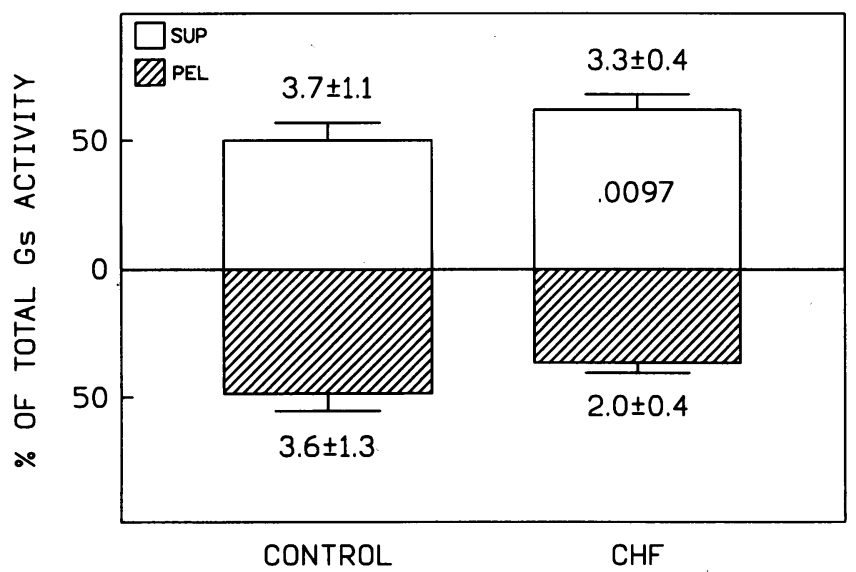

Figure 8. Distribution of Gs activity between supernatant (open bars) and pellet ( $P E L$; cross-hatched bars) fractions of right atrial membrane homogenates as assessed by cholera toxin-catalyzed ADP-ribosylation. $51 \pm 7 \%$ of total Gs activity was found in the supernatant fraction in right atrial membranes from control animals. Right atrial membranes from animals with congestive heart failure (CHF) showed a redistribution of $G$ s to the supernatant fraction $(63 \pm 6 \%$; $P=0.0097$ ). Data represent mean values from six animals in each group. Error bars denote $1 \mathrm{SD}$. Numbers above and below bars represent Gs activity in picomoles per gram wet weight.
Myocardial $\beta A R$ and adenylyl cyclase activity. Although no previous study has addressed alterations in $\beta A R$-mediated signal transduction in pacing-induced CHF in pigs, two prior studies using this model in dogs have been published $(6,7)$. Calderone et al. studied elements of $\beta$ AR-mediated signal transduction in RV and LV (6); Marzo et al. reported only on LV (7). Both of these investigations, similar to the present study, found downregulation of myocardial $\beta A R$ number, and depression of adenylyl cyclase activity whether stimulation was performed at the level of the $\beta \mathrm{AR}$, Gs, or the catalytic subunit. Marzo et al. found that receptor downregulation was selective for the $\beta_{1}$ receptor subtype ( 7 ), as we and others have reported in models of circulatory congestion and heart failure $(19,31)$. Thus, data regarding left ventricular $\beta$ AR expression and adenylyl cyclase activity is similar in dog and pig. It is of interest that recent preliminary data indicate that a decrease of mRNA for certain forms of the catalytic subunit of adenylyl cyclase may occur in the pacing-induced heart failure model in dogs $(32,33)$.

Cardiac Gi content. Decreased cardiac Gi content, according to current dogma, would be expected to increase signal transduction through the $\beta$ AR pathway. However, the extent to which variations in cardiac Gi content affect signal transduction through the myocardial $\beta \mathrm{AR}$ has not been systematically tested, and therefore is unknown. In fact, $\mathrm{Gi} \alpha_{2}$ may not directly inhibit adenylyl cyclase activity. When cDNAs for the three $\mathrm{Gi} \alpha$ subunits were expressed in Escherichia coli, a method that ensures purified $\alpha$ i subunits uncontaminated with $\beta \gamma$ dimers, their ability to inhibit adenylyl cyclase activity, even at high concentrations, was minimal (34). Other data suggest that the $\beta \gamma$ dimer, rather than dissociated $\alpha \mathrm{i}$, may lead to inhibition of adenylyl cyclase, either through direct interaction with the catalytic subunit, or through associating with free Gs $\alpha$, thereby preventing Gs $\alpha$-mediated stimulation of adenylyl cyclase (35). Our data provide strong evidence for decreased cardiac 


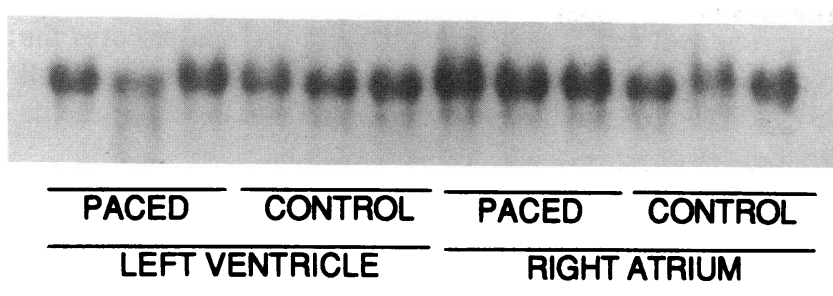

Figure 9. Northern blot showing hybridization of a 455-nucleotide porcine cardiac riboprobe for Gs $\alpha$ with total RNA from right atrial and left ventricular membranes from three control animals and three animals after signs of congestive heart failure (PACED) were evident. Each lane was loaded with $20 \mu \mathrm{g}$ total RNA. Left ventricular Gs $\alpha$ mRNA levels were not different between paced and control animals. However, right atrial Gs $\alpha$ mRNA levels were significantly increased $(P<0.04)$ after pacing-induced $\mathrm{CHF}$.

Gi content, in conjunction with striking depression of $\beta \mathrm{AR}$ mediated signal transduction, suggesting that increased cardiac $\mathrm{Gi}$ is not a necessary component for heart failure in this model. These data suggest that the pathophysiological role played by apparent increases in cardiac $\mathrm{Gi}$ in other models may require further examination.

Calderone et al. (6) assessed LV Gi by pertussis toxin-catalyzed ADP-ribosylation and found a $48 \%$ decrease in pertussis toxin substrate. Because pertussis toxin labels $\mathrm{Go}$ as well as $\mathrm{Gi}$, the addition of immunoblotting, as performed in the current study, is a more specific measure for Gi. Although Marzo et al. performed both pertussis toxin labeling and immunoblotting, they found slight increases in pertussis toxin substrate, but no statistically significant change in Gi content as assessed by immunoblotting (7). Neither of these studies examined chambers other than the LV for alterations in Gi. Our data confirm and extend the findings of Calderone et al. by examining tissue from both RA and LV and by performing quantitative immunoblotting in addition to ADP ribosylation. We believe that these data, for the first time, provide compelling evidence that cardiac $\mathrm{Gi}$ is decreased in this model of heart failure.

Three reports have shown increased LV Gi in CHF in humans (15-17). Furthermore, when cardiac myocytes are incubated with isoproterenol for $12-24 \mathrm{~h}, \mathrm{Gi} \alpha_{2}$ is increased, the transcription rate for $\mathrm{Gi} \alpha_{2}$ mRNA is increased, and message stability is unchanged (36). Some Gi genes have cAMP response elements (37), suggesting the possibility of a cAMPmediated increased transcription rate of $\mathrm{Gi} \alpha_{2}$. The $\mathrm{Gi} \alpha_{2}$ gene may lack cAMP response elements (38), so whether or not this mechanism occurs in vivo in CHF is unknown. If a heightened degree of adrenergic activation yields increased intracellular cAMP, as may be the case in early heart failure, findings from isolated cell studies could be applicable to the molecular pathophysiology of increased $\mathrm{Gi}$ in LV in human CHF. On the other hand, how could such a mechanism persist in advanced severe heart failure, when adenylyl cyclase activation is depressed, and intracellular levels of cAMP low (39)? Increased LV Gi is not a consistent finding in animal models of acquired CHF or circulatory congestion (19, 40-42). Inconsistent data may reflect differences between species, etiology of heart failure, or the added influence of prolonged pharmacological treatment, present in human, but not animal models. In the current study we used pacing-induced CHF, a much used animal model of
CHF that allows detailed biochemical and molecular studies. Animals were not treated with pharmacological agents, and had a uniform etiology for CHF.

Cardiac Gs content. Decreased cardiac Gs was demonstrated in both chambers by three independent means of evaluation. The functional consequence of decreased levels of Gs were established in cyc- reconstitution assays. Other studies of animal models of heart failure or circulatory congestion have reported that cardiac $G$ s is decreased $(19,42)$ but there has not been uniform agreement. Human heart failure has been associated with no change (15), or decreased levels of cardiac Gs $(42-44)$. We have found recently that when myocardial Gs content is measured in assays that use routine tissue preparation methods, a substantial portion of total Gs is discarded with the supernatant fraction after centrifugation (45). Indeed, both cholera toxin labeling and immunoblotting shows that up to $50 \%$ of the total Gs distributes to the supernatant. We have previously shown that the supernatant activity is not caused by membrane contamination of the supernatant (45). Redistribution of Gs $\alpha$ to the cell cytosol after receptor activation has been reported in isolated cell models (46). The current study, for the first time, provides evidence that Gs redistribution may represent an important mechanism by which Gs is downregulated after sustained $\beta A R$ activation in vivo. RA and $L V$ membranes from paced animals showed not only downregulation of Gs, but an increased proportion of Gs in the supernatant. These data are consistent with the hypothesis that persistent catecholamine stimulation of $\beta$-adrenergic receptors, as seen in heart failure, may lead to redistribution of $G$ s to the cell cytosol, and perhaps then to degradation. The decrease in Gs, shown by three independent methods of measuring Gs, coupled with the fact that steady state levels of Gs $\alpha$ mRNA are increased (RA) or unchanged (LV), suggests that increased Gs degradation rather than decreased Gs synthesis is the mechanism by which Gs is downregulated in this model of heart failure. Until quantitation of Gs $\alpha$ mRNA transcription rate and mRNA stability can be made, the conclusion that transcriptional regulation is not involved in reduced Gs $\alpha$ expression in heart failure must be restrained. Furthermore, the possibility that translational modifications may be of mechanistic importance in reduced G-protein expression has not been excluded.

In lymphoma cells the stoichiometry of elements of the $\beta A R-G s-a d e n y l y l$ cyclase complex suggests that levels of Gs exceed both $\beta A R$ number and levels of adenylyl cyclase (47). If the porcine cardiac myocyte also has "spare" Gs, could a 20$27 \%$ decrease in Gs, as we report here, have biological meaning? We previously found that a $42 \%$ increase in RA Gs was associated with a $57 \%$ increase in the efficacy of isoproterenol to stimulate heart rate, suggesting that levels of cardiac Gs may determine signal transduction efficiency (12). In heart failure, therefore, even though the amounts of adenylyl cyclase and $\beta A R$ number may set limits upon maximal responsiveness, a decreased amount of Gs, albeit small, may further impair signal transduction efficiency.

Only one prior study has examined cardiac Gs in a canine model of pacing-induced heart failure (7). They found no change in Gs function as assessed by reconstitution assays conducted on LV membranes. While there may be a species difference in Gs response in this model of heart failure, we are impressed with the similarities in $\beta A R$ expression and adenylyl cyclase activity between these species. 
Immunoblotting vs ADP ribosylation. The amounts of $\mathrm{Gi} \alpha_{2}$ and $\mathrm{Gs} \alpha$ as measured by quantitative immunoblotting is $60-$ 100 -fold greater than the amount of pertussis toxin or cholera toxin substrates (Figs. 5 and 6). Since membrane preparations for these studies were identical, this suggests that bacterial toxin substrates are less accessible to ADP-ribosylation than $\mathrm{Gi} \alpha_{2}$ and $\mathrm{Gs} \alpha$ are to interaction with specific antibodies. It is of interest that despite these striking differences in quantitative capacity, both techniques (ADP ribosylation and immunoblotting) yield very similar relative changes in $\mathrm{Gi}$ and $\mathrm{Gs}$ in CHF. No prior studies have provided quantitative data expressed as activity per gram of tissue using both immunoblotting and ADP ribosylation in the heart. The activity of Gs per milligram protein that we find by quantitative immunoblotting is very similar to the amount that we previously reported by ELISA (12). Similar values obtained by two different techniques provide a high level of confidence in the quantitative capacity of our measurements.

Implications of the data. A word of caution is in order regarding the application of these data to the pathophysiology of heart failure. In a previous study we used aortocaval fistulas to induce volume overload and a congested circulatory state (19). This model is characterized by high cardiac output, normal cardiac function, and high plasma catecholamines. Despite normal cardiac performance, the volume-overloaded congested state was associated with abnormalities in myocardial $\beta A R$ expression, adenylyl cyclase activity, and Gs function which are almost identical to the findings of the present study. Thus, in two models with striking differences in LV function, elements of the $\beta$ AR-Gs-adenylyl cyclase pathway are almost identical. This implies that the primary lesion in pacing-induced heart failure (and perhaps other models of dilated, systolic heart failure) is distal to adenylyl cyclase activation. Perhaps the contractile apparatus itself, or activation of sarcoplasmic reticulum calcium channels is abnormal in pacing-induced CHF. Recent data suggest that sustained agonist stimulation can result in decreased amounts of phospholamban (48), a key sarcoplasmic reticulum protein which regulates the $\mathrm{Ca}^{2+}$-ATPase channel. This implies that alterations in cell surface receptor number and adenylyl cyclase activity may simply reflect homeostatic adjustments secondary to sustained sympathetic activation, rather than being of primary mechahistic importance in the pathogenesis of heart failure.

Conclusions. There are striking similarities between human dilated cardiomyopathy and pacing-induced heart failure in pigs. Both types of heart failure are associated with cardiac dilatation, increased plasma and decreased myocardial catecholamine contents, and downregulation of myocardial $\beta$ ARs and adenylyl cyclase activity. However, unlike human heart failure, where increased cardiac $\mathrm{Gi}$ is found, $\mathrm{Gi}$ is downregulated in pacing-induced heart failure. Thus, levels of cardiac Gi alone are not predictive of adrenergic responsiveness or cardiac function in heart failure. Reduced levels of cardiac Gs are associated with increased (RA) or unchanged (LV) steady state levels of Gs $\alpha$ mRNA in pacing-induced heart failure, suggesting that reduced Gs may reflect increased Gs $\alpha$ degradation rather than decreased Gs $\alpha$ synthesis. An important step in Gs degradation may be redistribution of Gs $\alpha$ to the cell cytosol after $\beta$ AR activation. The remarkably similar alterations in the $\beta$ AR-Gs-adenylyl cyclase pathway in pacing-induced heart failure (poor LV function) and circulatory congestion induced by aorto-caval fistula (normal LV function) underscores the importance of intracellular events beyond the activation of cell surface receptors as fundamental determinants of contractile function.

\section{Acknowledgments}

We thank Dr. Michael Ziegler, who performed the catecholamine quantifications, and Medtronics Incorporated, who generously provided the pacemakers.

This work was supported by Merit and Research Career Development Awards from the Department of Veterans Affairs, grant S121-89 from the California Affiliate of the American Heart Association, and Specialized Center of Research on Coronary and Vascular Diseases HL-17682-18 (H. K. Hammond); grant 90-69 from the California Affiliate of the American Heart Association (D. A. Roth); grant 90-77 from the California Affiliate of the American Heart Association, and a grant from the Japan Heart Foundation (K. Urasawa). Dr. Helmer is an Associate Investigator of the Veteran's Administration. Dr. Hammond is also supported by National Institutes of Health Research Career Development Award HL-02812-01.

\section{References}

1. Whipple, G. H., L. T. Sheffield, E. G. Woodman, C. Theophilis, and S. Friedman. 1962. Reversible congestive heart failure due to chronic stimulation of the normal heart. Proc. New Engl. Cardiovasc. Soc. 20:39-40.

2. Coleman, H. N., R. R. Taylor, P. E. Pool, G. H. Whipple, J. W. Covell, J. Ross, and E. Braunwald. 1971. Congestive heart failure following chronic tachycardia. Am. Heart J. 81:790-798.

3. Wilson, J. R., P. Douglas, W. F. Hickey, V. Lanoce, N. Fararo, A. Muham$\mathrm{mad}$, and N. Reichek. 1987. Experimental congestive heart failure produced by rapid ventricular pacing in the dog: cardiac effects. Circulation. 75:857-867.

4. Armstrong, P. W., S. E. Stopps, S. E. Ford, and A. J. de Bold. 1986. Rapid ventricular pacing in the dog: pathophysiologic studies of heart failure. Circulation. 74:1075-1084.

5. Riegger, A. J. G., G. Liebau, M. Holzschuh, D. Witkowski, H. Steilner, and K. Koschsiek. 1984. Role of the renin-angiotensin system in the development of congestive heart failure in the dog as assessed by chronic converting enzyme blockade. Am. J. Cardiol. 53:614.

6. Calderone, A., M. Bouvier, K. Li, C. Juneau, J. de Champlain, and J.-L. Rouleau. 1991. Dysfunction of the $\beta$ - and $\alpha$-adrenergic systems in a canine model of congestive heart failure. Circ. Res. 69:332-343.

7. Marzo, K. P., M. J. Frey, J. R. Wilson, B. T. Liang, D. R. Manning, V. Lanoce, and P. B. Molinoff. 1991. $\beta$-Adrenergic receptor-G protein-adenylate cyclase complex in experimental canine congestive heart failure produced by rapid ventricular pacing. Circ. Res. 69:1546-1556.

8. Helmer, G. A., D. A. Roth, C. E. Ford, and H. K. Hammond. 1991. Left ventricular function and cardiac signal transduction after chronic rapid pacinginduced heart failure. Clin. Res. 39:343 A. (Abstr.)

9. Spinale, F. G., J. L. Zellner, M. Tomita, F. A. Crawford, and M. R. Zile. 1991. Relation between ventricular and myocyte remodeling with the development and regression of supra-ventricular tachycardia-induced cardiomyopathy. Circ. Res. 69:1058-1067.

10. Spinale, F. G., J. L. Zellner, M. Tomita, G. E. Temple, F. A. Crawford, and M. R. Zile. 1991. Tachycardia-induced cardiomyopathy: effects on blood flow and capillary structure. Am. J. Physiol. 261:H140-H148.

11. Hammond, H. K., F. C. White, L. Brunton, and J. C. Longhurst. 1987. Association of decreased myocardial $\beta$-receptors and chronotropic response to isoproterenol and exercise in pigs following chronic dynamic exercise. Circ. Res. 60:720-726.

12. Hammond, H. K., L. A. Ransnas, and P. A. Insel. 1988. Non-coordinate regulation of cardiac Gs protein and $\beta$ adrenergic receptors by a physiological stimulus, chronic dynamic exercise. J. Clin. Invest. 82:2168-2171.

13. Hammond, H. K., D. A. Roth, C. E. Ford, G. W. Stamnas, M. G. Ziegler, and C. Ennis. 1992. Myocardial adrenergic denervation supersensitivity depends upon a post-receptor mechanism not linked with increased cAMP production. Circulation. 85:666-679.

14. Urasawa, K., D. A. Roth, R. McKay, C. E. Ford, P. A. Insel, and H. K. Hammond. 1991. Chamber-specific changes in GTP-binding proteins in pacinginduced heart failure in pigs. Circulation. 84:II-393.

15. Feldman, A. M., A. E. Cates, W. B. Veazy, R. E. Hershberger, M. R. Bristow, K. L. Baughman, W. A. Baumgartner, and C. Van Dop. 1988. Increase 
in the 40,000-mol wt pertussis toxin substrate (G-protein) in the failing human heart. J. Clin. Invest. 82:189-197.

16. Neumann, J., W. Schmidtz, H. Schultz, L. von Meyerinck, V. Doring, and P. Kalmar. 1988. Increase of myocardial Gi proteins in human heart failure. Lancet. ii:936-937.

17. Bohm, M., P. Gierschik, K. H. Jacobs, B. Pieske, P. Schnabel, M. Ungerer, and E. Erdmann. 1990. Increase of Gi $\alpha$ in human hearts with dilated but not ischemic cardiomyopathy. Circulation. 82:1249-1265.

18. Odura, K. A. 1975. Glycopyrrolate methylbromide: comparison with atropine sulfate. Can. Anaesth. Soc. J. 22:466-473.

19. Hammond, H. K., D. A. Roth, P. A. Insel, C. E. Ford, F. C. White, M. G. Ziegler, A. S. Maisel, and C. M. Bloor. 1992. Myocardial $\beta$-adrenergic receptor expression and signal transduction after chronic volume overload hypertrophy and circulatory congestion in pigs. Circulation. 85:269-280.

20. Bradford, M. M. 1976. A rapid and sensitive method for the quantification of microgram quantities of protein utilizing the principle of protein dye binding. Anal. Biochem. 72:248-254.

21. Bers, D. M. 1979. Isolation and characterization of cardiac sarcolemma. Biochim. Biophys. Acta. 555:131-146.

22. Salomon, Y., C. Londos, and M. Rodbell. 1974. A highly sensitive adenylate cyclase assay. Anal. Biochem. 58:541-548.

23. Laemmli, U. K. 1970. Cleavage of structural proteins during the assembly of the head of bacteriophage T4. Nature (Lond.). 227:680-683.

24. Katada, T., and M. Ui. 1982. Direct modification of the membrane adenylate cyclase system by islet-activating protein due to ADP-ribosylation of a membrane protein. Proc. Natl. Acad. Sci. USA. 79:3129-3134.

25. Longabaugh, J. P., D. E. Vatner, R. M. Graham, and C. J. Homcy. 1986. $\mathrm{NADP}^{+}$improves the efficiency of cholera toxin catalyzed ADP-ribosylation in liver and heart membranes. Biochem. Biophys. Res. Commun. 37:328-333.

26. Nagai, K., and H.C. Thogersen. 1984. Generation of $\beta$-globin by sequence specific proteolysis of a hybrid protein produced in Escherichia coli. Nature (Lond.). 309:810-812.

27. Towbin, H., S. Theophil, and J. Gordon. 1979. Electrophoretic transfer of proteins from polyacrylamide gels to nitro-cellulose sheets: procedure and some applications. Proc. Natl. Acad. Sci. USA. 76:4350-4354.

28. Gierschik, P., G. Milligan, M. Pines, P. Goldsmith, J. Codina, W. Klee, and A. Spiegel. 1986. Use of specific antibodies to quanitate the guanine nucleotide-binding protein Go in brain. Proc. Natl. Acad. Sci. USA. 83:2258-2262.

29. Sternweiss, P. C., J. K. Northrup, M. D. Smigel, and A. G. Gilman. 1981 Regulatory component of adenylate cyclase: purification and properties. J. Biol. Chem. 256:11517-11526.

30. Durrett, L. R., and M. G. Ziegler. 1980. A sensitive radio-enzymatic assay for catechol drugs. J. Neurosci. Res. 5:587-598.

31. Bristow, M. R., R. Ginzburg, V. Umans, M. Fowler, W. Minobe, R. Rasmussen, P. Zera, R. Menlove, P. Shah, S. Jamieson, and E. B. Stinson. 1986 $\beta_{1}$ and $\beta_{2}$ adrenergic receptor subpopulations in nonfailing and failing human ventricular myocardium: coupling of both receptor subtypes to muscle contraction and selective $\beta_{1}$ receptor down-regulation in heart failure. Circ. Res. 59:297309.

32. Ishikawa, Y., S. Katsushika, L. Chen, K. Kiuchi, K. Komamura, R. P. Shannon, D. E. Vatner, S. F. Vatner, and C. J. Homcy. 1992. Reduced steady state mRNA levels of cardiac adenylyl cyclase ( $\mathrm{AC}$ ) parallels the development of heart failure. Clin. Res. 40:220A. (Abstr.)

33. Ishikawa, Y., S. Katsushika, J. Kawabi, D. E. Vatner, and C. J. Homcy. 1992. Characterization of novel members of cardiac adenylyl cyclase family:
mRNA levels parallel the development of heart failure. Circulation. 86:I-767. (Abstr.)

34. Linder, M. E., D. A. Ewald, R. J. Miller, and A. G. Gilman. 1990. Purification and characterization of Go $\alpha$ and three types of Gi $\alpha$ after expression in Escherichia coli. J. Biol. Chem. 265:8243-8251.

35. Katada, T., J. K. Northrup, G. M. Bokoch, M. Ul, and A. G. Gilman. 1984. The inhibitory guanine nucleotide-binding regulatory component of adenylate cyclase. Subunit dissociation and guanine nucleotide-dependent hormonal inhibition. J. Biol. Chem. 259:3578-3585.

36. Eschenhagen, T., U. Mende, M. Nose, W. Schmidz, H. Scholz, A. Warnholtz, and J.-M. Wustel. 1991. Isoprenalin-induced increase in mRNA levels of inhibitory G-protein $\alpha$-subunit in rat heart. Naunyn-Schmiedeberg's Arch. Pharmacol. 343:609-615.

37. Brann, M. R., R. M. Collins, and A. Spiegel. 1987. Localization of mRNAs encoding the $\alpha$-subunits of signal transducing G-proteins within rat brain and among peripheral tissues. FEBS (Fed. Eur. Biochem. Soc.) Lett. 222:191-198.

38. Luetje, C. W., M. Tietje, J. L. Christian, and N. M. Nathanson. 1988. Differential tissue expression and developmental regulation of guanine nucleotide binding regulatory proteins and their messenger RNAs in rat heart. J. Biol. Chem. 263:13357-13365.

39. Feldman, M. D., L. Copelas, J. K. Gwathmey, J. K. Phillips, and S. Warren. 1987. Deficient production of cyclic AMP: pharmacological evidence of an important cause of contractile dysfunction in patients with end-stage heart failure. Circulation. 75:331-339.

40. Katoh, Y., I. Komuro, F. Takaku, H. Yamaguchi, and Y. Yazaki. 1990. Messenger RNA levels of guanine nucleotide-binding proteins are reduced in the ventricle of cardiomyopathic hamsters. Circ. Res. 67:235-239.

41. Longabaugh, J. P., D. E. Vatner, S. F. Vatner, and C. J. Homcy. 1988. Decreased stimulatory guanosine triphosphate binding protein in dogs with pressure-overload left ventricular failure. J. Clin. Invest. 81:420-424.

42. Urasawa, K., and P. A. Insel. 1992. GTP-binding proteins and cardiovascular disease. In G Proteins: Signal Transduction and Disease. Academic Press, London. 44-85.

43. Horn, E. M., S. J. Corwin, S. F. Steinberg, Y. K. Chow, G. W. Neuberg, P. J. Cannon, E. R. Powers, and J. P. Bilezikian. 1988. Reduced lymphocyte stimulatory guanine nucleotide regulatory protein and $\beta$-adrenergic receptors in congestive heart failure and reversal with angiotensin converting enzyme inhibitor therapy. Circulation. 78:1373-1379.

44. Ransnas, L. A., A. Hjalmarson, and P. A. Insel. 1988. Dilated cardiomyopathy is associated with an impaired activation of the stimulatory $G$ protein, $G_{s}$, by GTP in heart membranes. Circulation. (Suppl). 78:II-178. (Abstr.)

45. Roth, D. A., K. Urasawa, D. Leiber, P. A. Insel, and H. K. Hammond. 1992. A substantial proportion of cardiac $G_{2}$ is not associated with the plasma membrane. FEBS (Fed. Eur. Biochem. Soc.) Lett. 296:46-50.

46. Negishi, M., H. Hashimoto, and A. Ichikawa. 1992. Translocation of $\alpha$ subunits of stimulatory guanine nucleotide-binding proteins through stimulation of the prostacyclin receptor in mouse mastocytoma cells. J. Biol. Chem. 267:2364-2369.

47. Alousi, A. A., J. R. Jasper, P. A. Insel, and H. J. Motulsky. 1991. Stoichiometry of receptor-Gs-adenylate cyclase interactions. FASEB (Fed. Am. Soc. Exp. Biol.) J. 5:2300-2303.

48. Bowling, N. L., S. Hayes, and L. R. Jones. 1989. Down-regulation of cardiac phospholamban in response to chronic $\beta$-adrenoreceptor stimulation. Circulation. (Suppl.) 80:II-292. 